\title{
Surgical treatment of distal tibia fractures: open versus MIPO
}

\author{
Deniz Gülabi, M.D., ${ }^{1}$ Haliı İbrahim Bekler, M.D., ${ }^{1}$ Fevzi Sağlam, M.D., ${ }^{1}$ \\ Zeki Taşdemir, M.D., ${ }^{1}$ Gültekin Sıtkı Çeçen, M.D., ${ }^{1}$ Nurzat Elmalı, M.D. ${ }^{2}$
}

${ }^{1}$ Department of Orthopaedics and Traumatology, Dr. Lütfi Kırdar Kartal Training and Research Hospital, İstanbul, Turkey ${ }^{2}$ Department of Orthopaedics and Traumatology, Bezmiâlem Vakif University Faculty of Medicine, İstanbul, Turkey

\begin{abstract}
BACKGROUND: Treatment of the distal tibial fractures are challenging due to the limited soft tissue, subcutaneous location and poor vascularity. In this control-matched study, it was aimed to compare the traditional open reduction and internal fixation with minimal invasive plating (MIPO). We hypothesized that superior results may be achieved with MIPO technique.

METHODS: 22 patients treated with traditional open reduction and internal fixation were matched with 22 patients treated with closed reduction and MIPO on the basis of age $( \pm 3)$, gender, and fracture pattern (AO classification). Evaluation was assed according to the wound problems, the American Orthopaedic Foot and Ankle surgery (AOFAS) scoring, radiological union, malunion, delayed union, hospitalisation time, time from injury to surgery, and operation time.
\end{abstract}

RESULTS: There was no significant difference in the distribution of AO/OTA classification, age, gender, AOFAS score, time from injury to operation, follow-up, bone union time, delayed union, malunion and infection $(p>0.05)$. The operation time was significantly longer in the open group than in the MIPO group: $69.59 \pm 7.21 \mathrm{~min}$. for the ORIF, and $6 \mathrm{I} .14 \pm 5.6 \mathrm{I}$ for the MIPO group ( $<<0.0 \mathrm{I}$ ). The hospitalisation time was significantly longer in the open group than in the MIPO group: $7.64 \pm 4.7 \mathrm{I}$ days for the MIPO, and I0.I8 \pm 4.32 days for the ORIF group $(\mathrm{p}<0.05)$.

CONCLUSION: MIPO technique can be beneficial for the treatment of distal tibia AO/OTA A and B type fractures with reduced hospital stay, cost-effectiveness, and infection rate.

Key words: Distal tibia; fracture; malunion; MIPO.

\section{INTRODUCTION}

Distal tibia fractures are a common result of traffic accidents and fall injuries. ${ }^{[1]}$ The treatment of distal tibial fractures is challenging due to the limited soft tissue, subcutaneous location and poor vascularity. ${ }^{[2,3]}$ Fracture pattern (proximity of the fracture to the plafond, comminution), soft tissue injury, and bone quality critically influence the selection of the fixation technique. ${ }^{[4]} \mathrm{A}$ variety of treatments may be used, including external fixation, intramedullary nailing, and plate fixation. ${ }^{[1,5]}$

Address for correspondence: Fevzi Sağlam, M.D.

Dr. Lütfi Kırdar Kartal Eğitim ve Araştırma Hastanesi,

Ortopedi ve Travmatoloji Kliniği, Kartal, İstanbul, Turkey

Tel: +90 216 - 44I 3900 E-mail: fvzisaglam@hotmail.com

Qucik Response Code Ulus Travma Acil Cerrahi Derg

2016;22(I):52-57

doi: $10.5505 /$ tjtes.2015.82026

Copyright 2016

TJTES
Traditonal open reduction and internal plate fixation (ORIF) achieves an acceptable reduction and rigid fixation, but requires extensive soft tissue dissection and periosteal stripping, and these factors inrease the rates of complications, including infection, delayed union and nonunions. ${ }^{[6,7]}$ Minimally invasive plate osteosynthesis techniques has been developed in recent years, ${ }^{\left[{ }^{[}\right]}$with high union rates. ${ }^{[8]}$ This technique aims to reduce surgical trauma and maintain a more biologically favorable environment for fracture healing. However, complications, such as angular deformities, hardware failure, and nonunions have been reported. ${ }^{[9-11]}$

In this control-matched study, it was aimed to compare traditional open reduction and internal fixation with minimal invasive plating (MIPO). We hypothesized that superior results may be achieved with the MIPO technique.

\section{MATERIALS AND METHODS}

The study was undertaken at the department of Orthopaedics and Traumatology at Kartal Training and Research Hospi- 
tal, and was approved by the Local Ethical Committees, dated and numbered II.02.20I4-895/3307/I009/255, of the same hospital. All patients signed an informed consent statement. From January 2008 to May 20 I I, ninety-two cases of distal tibia fractures were operated according to the medical record charts. Inclusion criteria of the study were distal tibia metadiaphyseal fractures, closed or Gustillo-Anderson grade I open fractures, and skeletally mature patients. The fractures were classified according to the Orthopaedic Trauma Association $^{[12]}$ classification. Ten patients were excluded since they had ipsilateral fractures, five patients were excluded due to pathological fractures, five patients were excluded due to lack of follow-up, eight patients with open fractures according to Gustilo and Anderson type II or type III $^{[13]}$ and four patients with a displaced intraarticular fragment were also excluded.

Among them, thirty-two patients were treated by MIPO and 28 by ORIF. Twenty-two patients treated with traditional open reduction and internal fixation were matched with 22 patients treated with closed reduction and MIPO on the basis of age $( \pm 3)$, gender, and fracture pattern (AO classification). All patients were operated on with locking compression plates. Anteroposterior and lateral radiographs of the involved limb were used to determine fracture pattern. All the operations were performed by the same AO certificated trauma surgeon (HIB). All patients' involved leg was immobilised by above knee Paris-plaster splint before surgery. Ice and mannitol (IV $250 \mathrm{mg}$ daily) were used preoperatively to decrease swelling. The operations were carried out when the skin appeared wrinkled.

\section{Surgical Procedure}

All the patients underwent operation on a standart radiolucent table in supine position. A tourniquet was used in both groups. In both groups, cefazoline $1000 \mathrm{mg}$ was used as prophylaxis 30 minutes prior to surgery and continued (I gr every eight hours) for 24 hours after surgery. In traditional open surgery, classic anteromedial exposure was used, the reduction was made under vision, and then locking compression plate was fixed with screws. At least 4 screws were preferred at both sides of the fracture. All plates were placed on the medial surface of the tibia. If the fracture line was oblique or spiral, one or two cortical screws were used as lag screws. Fixation of fibula fractures used to be considered unnecessary unless associated with syndesmotic instability, which was tested after tibial fixation (Figs. la-d).

In MIPO technique, closed reduction was made under fluoroscopic image. The reduction was achieved by ligamentotaxis with manual traction by a junior assistant and also weber clamp could be used for the assitance of reduction. A $3 \mathrm{~cm}$ anteromedial incision was made from $\mathrm{I} \mathrm{cm}$ proximal to the tip of medial maleol to the distal, the great saphaneous vein was protected and the appropiate plate was advanced upward subcutaneously without disturbing the periost. The plate was selected based on its length with the aid of fluoroscopy. There had to be at least three holes on both sides of the fracture site. Afterwards, a proximal incision about 2 holes long was made to expose the upper part of the plate, and the plate was positioned as needed. Once the clarification of the fracture reduction and plate position was accomplished, the screws were driven in with the assistance of fluoroscopy (Figs. 2a-d).

\section{Postoperative Management}

No drain was used in either group. After ORIF, the tourniqyet was deflated and bleeding control was made under careful attention. Both groups received same postoperative care. Active knee and ankle joint motion was allowed as soon as possible. When the postoperative swelling was diminished, all patients were encouraged to mobilise without weight bearing with two crutches. Progressive weight bearing was allowed once there was radiographic evidence of callus formation and also clinical union. Clinical union was defined as pain- free full weight-bearing, and the patients progressed to full weight
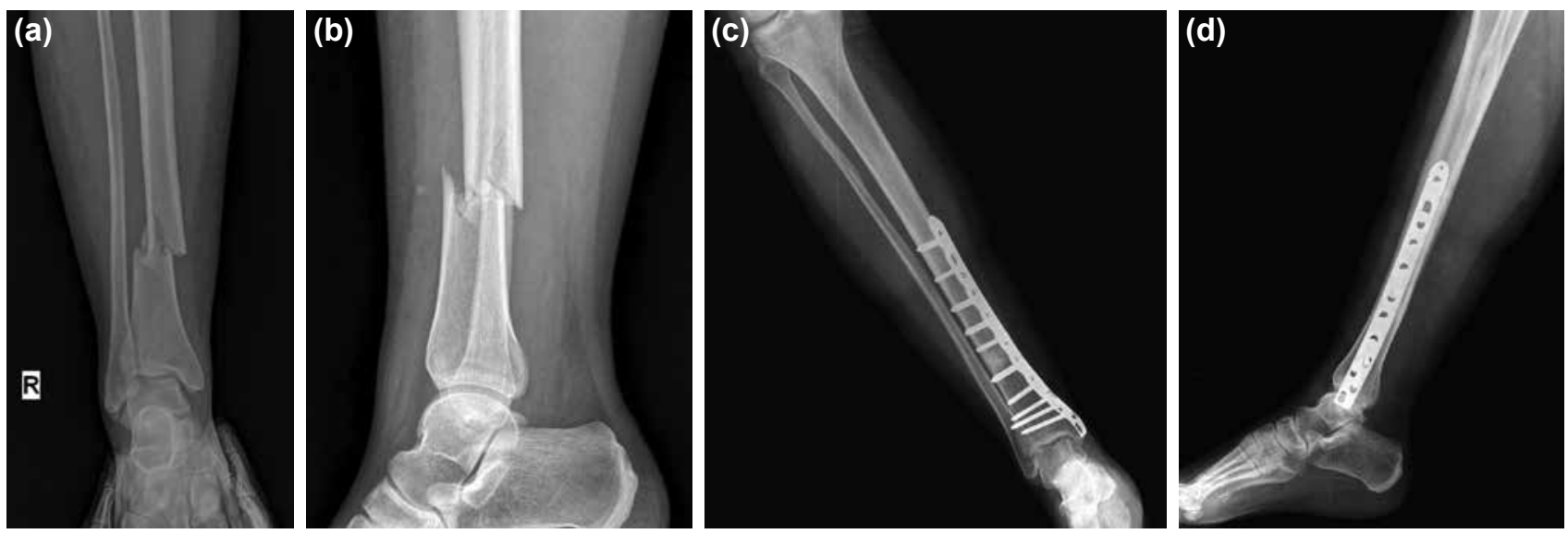

Figure 1. 33 years old female, injuried her right tibia after a traffic accident. She was operated with ORIF at 10 days post-injury. (a) Preoperative anteroposterior radiograph of the injuried tibia, (b) preoperative lateral radiograph of the injuried tibia (c) postoperative anteroposterior radiograph of the tibia at 18 months follow-up. Bony union was achieved. (d) Posopertative lateral radiograph of the tibia at 18 months follow-up. 

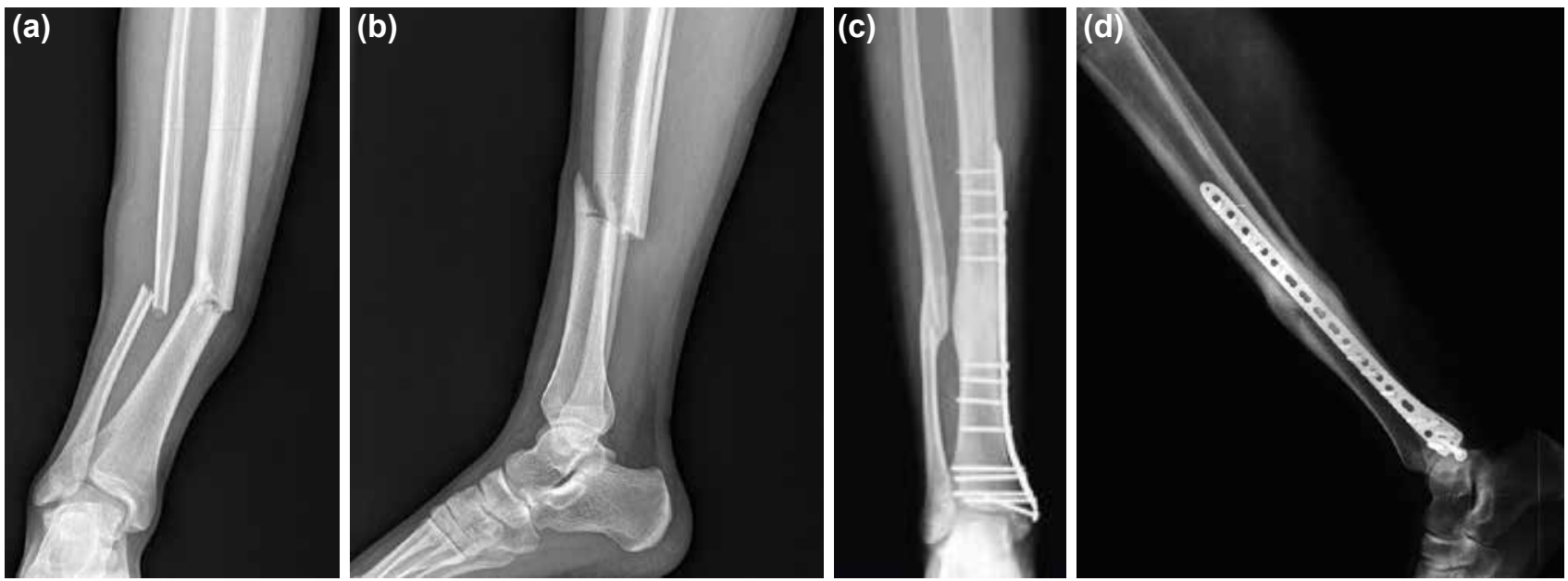

Figure 2. A 22 years old male was involved in a traffic accident sustained a closed right distal tibia fracture. The surgery was performed 9 days post-injury with MIPO technique. (a) Preoperative anteroposterior radiograph of the injuried tibia, (b) preoperative lateral radiograph of the injuried tibia (c) postoperative anteroposterior radiograph of the tibia at two years follow-up. Bony union was achieved. (d) Posopertative lateral radiograph of the tibia at two years follow-up.

bearing after bone union. Radiographic union was defined as the presence of callus in three of the four cortices as seen on antero-posterior and lateral radiographs. Radiographs were assessed by a trained reviewer not involved in the patients' care. Malunion was defined as more than five degrees of angular or rotational deformity. Delayed union was defined as lack of union at 24-26 weeks, and nonunion was defined as lack of healing at $>9$ months. Clinical evidence of infection (deep or superficial) was recorded. Deep infection was defined as below the muscular fascia. Superficial infection was confined to the dermal and subcutaneous tissue, and persistent drainage from the wound for at least two days.

The patients were followed up clinically and radiologically at intervals of four weeks until bony union was achieved. After bony union was achieved, the patients were followed up at 3 months interval for the first year, and at 6 months interval for the second year and annually. Evaluation was assed according to wound problems, the American Orthopaedic Foot and Ankle surgery (AOFAS) scoring, ${ }^{[14]}$ radiological union, malunion, delayed union, hospitalisation time, time from injury to surgery, and operation time.

\section{Statistical Analysis}

The groups were compared with respect to gender, age, AO fracture type, hospitalisation, time from injury to surgery, operating time, bone healing time, incidence of complications, and AOFAS scores. An independent statistician, who was not directly involved in the study, performed the statistical analysis. The SPSS program (Statistical Package for Social Sciences) for Windows 15.0 was used for the evaluation of data obtained in the study. Descriptive statistical methods (mean, standard deviation, median, percentage, ratio) were used in the evaluation of data and for the analysis of the relationship beween parameters and Student's $t$ test was used for the interval (age, healing time, follow-up, operation time and AOFAS). Mann-Whitney $U$ test was used for the interval (interval from injury to surgery, hospital stay). Continuity correction yates test was used for the interval (gender, AO/OTA classification). Fischer's exact test was used for the interval (nonunion, delayed union, malunion, infection). The chosen level of significance was $p<0.05$.

\section{RESULTS}

Table I presents the demographic data and all outcomes for the two groups that were cross-matched. There was no significant difference in the distribution of AO/OTA classification, age, gender, and AOFAS score $(p>0.05)$ (Table I).

The operation time was significantly longer in the open group than in the MIPO group: $69.59 \pm 7.21 \mathrm{~min}$. for the ORIF, and $6 I .14 \pm 5.6 I$ for the MIPO group $(p<0.01)$.

There was no significant difference in the distribution of time from injury to operation, follow-up, bone union time, delayed union, malunion and infection $(p>0.05)$.

The hospitalisation time was significantly longer in the open group than in the MIPO group: $7.64 \pm 4.7$ I days for the MIPO, and $10.18 \pm 4.32$ days for the ORIF group $(p<0.05)$. Three fibula fractures were fixed in both groups due to the syndesmotic instability.

Compression plates were used in both groups. All the fractures in both groups healed without the need for secondary procedures. There were two superficial wound infections in the ORIF group, which resolved with daily wound care. At the last follow-up visits, the fractures were healed radiologically, and the patients walked without pain and assistance. 
Table I. Comparison of the main data for both groups of patients

\begin{tabular}{|c|c|c|c|c|c|c|c|}
\hline & \multicolumn{3}{|c|}{ Minimal invasive plating } & \multicolumn{3}{|c|}{ Opened } & \multirow[t]{2}{*}{$\mathbf{p}$} \\
\hline & $\mathbf{n}$ & $\%$ & Mean $\pm S D$ & $\mathbf{n}$ & $\%$ & Mean \pm SD & \\
\hline Age (year) (median) & & & $39.95 \pm 13.75$ & & & $41.68 \pm 16.30$ & $' 0.706$ \\
\hline Gender (male) & 14 & 63.6 & & 14 & 63.6 & & ${ }^{3} 1.000$ \\
\hline Gender (female) & 8 & 36.4 & & 8 & 36.4 & & \\
\hline AOFAS & & & $78.73 \pm 4.72$ & & & $78.82 \pm 7.46$ & '0.962 \\
\hline \multicolumn{8}{|l|}{ AO Classification } \\
\hline Type A & 16 & 72.7 & & 16 & 72.7 & & ${ }^{3} 1.000$ \\
\hline Type B & 6 & 27.3 & & 6 & 27.3 & & \\
\hline Duration of surgery (min) (median) & & & $69.59 \pm 7.21$ & & & $61.14 \pm 5.61$ & $10.00 I^{* *}$ \\
\hline Interval from injury to surgery (days) (median) & & & $5.91 \pm 4.55(5)$ & & & $6.68 \pm 4.26(6)$ & ${ }^{2} 0.464$ \\
\hline Hospital stay (days) (median) & & & $7.64 \pm 4.71(6)$ & & & $10.18 \pm 4.32(9)$ & ${ }^{2} 0.023^{*}$ \\
\hline Follow-up time (months) & & & $21.77 \pm 3.08$ & & & $21.91 \pm 2.94$ & $' 0.881$ \\
\hline Healing time (weeks) & & & $15.82 \pm 4.18$ & & & $17.48 \pm 4.86$ & $' 0.237$ \\
\hline Infection & 0 & 0 & & 2 & 9.1 & & ${ }^{4} 0.488$ \\
\hline Delayed union & 2 & 9.1 & & 2 & 9.1 & & ${ }^{4} I .000$ \\
\hline Malunion & 2 & 9.1 & & 0 & 0 & & ${ }^{4} 0.488$ \\
\hline
\end{tabular}

'Student t test; ${ }^{2}$ Mann-Whitney $U$ test; ${ }^{3}$ Yates's continuity correction test; ${ }^{4}$ Fisher's Exact test; ${ }^{*} p<0.05 ;{ }^{* *} p<0.0$ I.

AOFAS: American Orthopaedic Foot and Ankle surgery; AO: American Orthopaedic; SD: Standard deviation.

\section{DISCUSSION}

MIPO technique is a method based on biological osteosynthesis, which is depended on preservation on fracture haematoma, minimal soft tissue dissection. Successful radiological and clinical outcomes were recommended with this technique. ${ }^{[15-17]}$ Traditional open surgical technique is based on absolute stability achieved by full contact at the fracture side, and rigid internal fixation; however, open surgery has some limitations, such as infection, and long hospital stay. ${ }^{[5]}$

Delayed union, and nonunions are important morbidities in the treatment of distal tibia fractures and common findings. Li et al. ${ }^{\left[{ }^{1]}\right.}$ have reported no delayed union or nonunion in their retrospective study involving twenty-threepatients treated with MIPO. Guo et al. ${ }^{[6]}$ reported no delayed union or nonunion in their prospective randomised study involving forty-one patients treated with MIPO. Seyhan et al. ${ }^{[5]}$ have reported two $(5.6 \%)$ nonunion with MIPO in their retrospective study. Zou et al. ${ }^{[15]}$ have reported three $(7.1 \%)$ delayed union with open surgery. In the current study, two patients in the MIPO group and two patients in the conventional open surgery group had delayed union, there was no statistically significant difference between each group with respect to the delayed union and nonunion parameters $(p<0.05)$. The patients with delayed union in the open surgery group suffered from high energy trauma and A3 fractures, therefore, we are of the opinion that stripping the periosteum in open surgery can promote the delay in bone healing. The two patients with delayed union in the MIPO group were heavy smokers. Tobacco has negative effect on bone healing.

Lee et al. ${ }^{[18]}$ have recommended that they had only three (3.4\%) malunions in eighty-eight distal tibia fractures treated with open plating. Zou et al. ${ }^{[15]}$ have reported no malunion in their study with open surgery. Recently, malunion has been common in the MIPO technique, ranging from $2 \%$ to $35 \%$. ${ }^{[5,19-21]}$ Zou et al. ${ }^{[15]}$ have reported that malunion was seen in $9.6 \%$ of the patients treated with MIPO. The rate of malunion was $9.5 \%$ in Borg et al.'s ${ }^{[22]}$ study with MIPO. In the current study, malunion was reported in two patients $(9.1 \%)$ in the MIPO group but none in the conventional open surgery, as it is difficult to achieve anatomic reduction of the fracture site with minimally invasive plating with indirect reduction.

There was no significant difference with respect to the time from injury to surgery in both groups $(p<0.05)$ : $5.91 \pm 4.55$ days for MIPO, and $6.68 \pm 4.26$ days for ORIF group. All surgeries were postulated till the wrinkle sign was diminished. Greater number of days in hospital causes higher hospital costs to society. In this retrospective cross-match study, the MIPO group had a significantly shorter hospital stay compared with open group $(p<0.05)$, which results in reduced healthcare-costs. As incision area was seen odematous and wound edges were seen dehiscence in the early postoperative days, the patients were followed- up closely, which resulted in long hospital stay. 
In the present study, two $(9.1 \%)$ superficial infections was noted in the ORIF group, whichresolved with local wound care. It is well-known that distal part of the tibia has poor vascularity and soft tissue coverage, so infection is a common complication. Lee et al. ${ }^{[18]}$ have stated seven (8.0\%) superficial infections, Jensen et al. ${ }^{[23]}$ have reported nine superficial infections (9\%) in one hundred and five patients treated with open plating. Guo et al. ${ }^{[16]}$ have reported 6 wound problems $(14.6 \%)$ in thirty-eight patients plated with MIPO technique. Open methods may have a higher infection rate than that of MIPO due to the risk of insufficient circulation at wound edges, which exposes to the superficial infection. ${ }^{[18]}$

In the current study, we did not find a statistically significant difference in functional outcome scores (AOFAS) between patients treated with MIPO and patients treated with the ORIF technique. We used the same postoperative management and rehabilitation protocol for both treatment groups.

The control-matched design study of the current study has some limitations. It was a retrospective study and not randomized. Secondly, the selection of the surgical technique bias cannot be avoided. In order to maintain a sufficient number of patients, the matching considered only gender, age, AO classification. The last one was that there was a lack of comparison of the $\mathrm{x}$-ray doses of the both group.

\section{Conclusion}

MIPO technique can be useful for the treatment of distal tibia AO/OTA A and B type fractures with reduced hospital stay, cost-effectiveness, and infection rate. Yet, further prospective, randomised studies comparing these two techniques are warranted to confirm the findings of this current study.

\section{Conflict of interest: None declared.}

\section{REFERENCES}

1. Li Y, Liu L, Tang X, Pei F, Wang G, Fang Y, et al. Comparison of low, multidirectional locked nailing and plating in the treatment of distal tibial metadiaphyseal fractures. Int Orthop 2012;36:1457-62.

2. Shon OJ, Park CH. Minimally invasive plate osteosynthesis of distal tibial fractures: a comparison of medial and lateral plating. J Orthop Sci 2012;17:562-6.

3. Tulner SA, Strackee SD, Kloen P. Metaphyseal locking compression plate as an external fixator for the distal tibia. Int Orthop 2012;36:1923-7.

4. Cheng W, Li Y, Manyi W. Comparison study of two surgical options for distal tibia fracture-minimally invasive plate osteosynthesis vs. open reduction and internal fixation. Int Orthop 2011;35:737-42.

5. Seyhan M, Unay K, Sener N. Intramedullary nailing versus percutane- ous locked plating of distal extra-articular tibial fractures: a retrospective study. Eur J Orthop Surg Traumatol 2013;23:595-601.

6. Im GI, Tae SK. Distal metaphyseal fractures of tibia: a prospective randomized trial of closed reduction and intramedullary nail versus open reduction and plate and screws fixation. J Trauma 2005;59:1219-23.

7. Janssen KW, Biert J, van Kampen A. Treatment of distal tibial fractures: plate versus nail: a retrospective outcome analysis of matched pairs of patients. Int Orthop 2007;31:709-14.

8. Ronga M, Longo UG, Maffulli N. Minimally invasive locked plating of distal tibia fractures is safe and effective. Clin Orthop Relat Res 2010;468:975-82.

9. Francois J, Vandeputte G, Verheyden F, Nelen G. Percutaneous plate fixation of fractures of the distal tibia. Acta Orthop Belg 2004;70:148-54.

10. Khoury A, Liebergall M, London E, Mosheiff R. Percutaneous plating of distal tibial fractures. Foot Ankle Int 2002;23:818-24.

11. Maffulli N, Toms AD, McMurtie A, Oliva F. Percutaneous plating of distal tibial fractures. Int Orthop 2004;28:159-62.

12. Fracture and dislocation compendium. Orthopaedic Trauma Association Committee for Coding and Classification. J Orthop Trauma 1996;10 Suppl 1:1-154.

13. Gustilo RB, Anderson JT. Prevention of infection in the treatment of one thousand and twenty-five open fractures of long bones: retrospective and prospective analyses. J Bone Joint Surg Am 1976;58:453-8.

14. Kitaoka HB, Alexander IJ, Adelaar RS, Nunley JA, Myerson MS, Sanders M. Clinical rating systems for the ankle-hindfoot, midfoot, hallux, and lesser toes. Foot Ankle Int 1994;15:349-53.

15. Zou J, Zhang W, Zhang CQ. Comparison of minimally invasive percutaneous plate osteosynthesis with open reduction and internal fixation for treatment of extra-articular distal tibia fractures. Injury 2013;44:1102-6.

16. Guo JJ, Tang N, Yang HL, Tang TS. A prospective, randomised trial comparing closed intramedullary nailing with percutaneous plating in the treatment of distal metaphyseal fractures of the tibia.J Bone Joint Surg Br 2010;92:984-8.

17. Collinge C, Protzman R. Outcomes of minimally invasive plate osteosynthesis for metaphyseal distal tibia fractures. J Orthop Trauma 2010;24:4-9.

18. Lee YS, Chen SH, Lin JC, Chen YO, Huang CR, Cheng CY. Surgical treatment of distal tibia fractures: a comparison of medial and lateral plating. Orthopedics 2009;32:163.

19. Helfet DL, Shonnard PY, Levine D, Borrelli J Jr. Minimally invasive plate osteosynthesis of distal fractures of the tibia. Injury 1997;28 Suppl 1:A42-8.

20. Toms AD, McMurtie A, Maffulli N. Percutaneous plating of the distal tibia. J Foot Ankle Surg 2004;43:199-203.

21. Krackhardt T, Dilger J, Flesch I, Höntzsch D, Eingartner C, Weise K. Fractures of the distal tibia treated with closed reduction and minimally invasive plating. Arch Orthop Trauma Surg 2005;125:87-94.

22. Borg T, Larsson S, Lindsjö U. Percutaneous plating of distal tibial fractures. Preliminary results in 21 patients. Injury 2004;35:608-14.

23. Jensen JS, Hansen FW, Johansen J. Tibial shaft fractures. A comparison of conservative treatment and internal fixation with conventional plates or AO compression plates. Acta Orthop Scand 1977;48:204-12. 
ORİJINAL ÇALIŞMA - ÖZET

\section{Distal tibia kırıklarında cerrahi tedavi: Açık veya MIPO?}

Dr. Deniz Gülabi, ${ }^{1}$ Dr. Halil İbrahim Bekler, ${ }^{1}$ Dr. Fevzi Sağlam,, ${ }^{1}$ Dr. Zeki Taşdemir, ${ }^{1}$ Dr. Gültekin Sıtkı Çeçen, ${ }^{1}$ Dr. Nurzat Elmalı ${ }^{2}$

${ }^{1}$ Dr. Lütfi Kırdar Kartal Eğitim ve Araştırma Hastanesi, Ortopedi ve Travmatolji Kliniği, İstanbul ${ }^{2}$ Bezmiâlem Vakıf Üniversitesi Tıp Fakültesi, Ortopedi ve Travmatoloji Anabilim Dalı, İstanbul

AMAÇ: Yetersiz cilt örtüsü, hemen cilt altinda olması ve zayıf kan dolaşımı nedeniyle distal tibia kırıkların cerrahi tedavisi tartışmalıdır. Bu olgu-kontrol çalışmasında geleneksel yerine oturtma, içerden tespit ile minimal invaziv (MIPO) plaklama yöntemini karşılaştırmayı amaçladık. Hipotezimiz ise MIPO yöntemiyle daha iyi sonuçların elde edilebileceğiydi.

GEREÇ VE YÖNTEM: Yaş (+3), cinsiyet ve kırık paterni (AO sınıflaması) esas alınarak; geleneksel yerine oturtma ve içerden tespit uygulanan 22 hasta, MIPO kullanılarak tedavi edilen 22 hasta ile kıyaslandı. Yara sorunları, Amerikan ayak ve ayak bileği cerrahi skorlaması (AOFAS), radyolojik kaynama, kötü kaynama, gecikmiş kaynama, hastanede yatış süresi, travmadan ameliyata kadar bekleme süresi ve operasyon süresi değerlendirme kriterleri olarak kullanıldı.

BULGULAR: Gruplar arasında AO/OTA kırık tipi, yaş, cinsiyet, AOFAS skoru, travmadan ameliyata kadar geçen süre, takip süresi, kaynama süresi, gecikmiş kaynama, kötü kaynama ve enfeksiyon açısından istatiksel olarak anlamlı fark saptanmadı. Operasyon süresi açık grupta MIPO grubuna kıyasla anlamlı şekilde uzun olduğu gözlendi. Hastanede yatış süresi açık cerrahi grubunda MIPO grubuna göre anlamlı şekilde uzun olduğu gözlendi. TARTIŞMA: Sonuç olarak, MIPO; kısalmış hastane kalış süresi, azalmış enfeksiyon oranı ve düşük maliyet nedeniyle distal tibia AO/OTA A ve B tip kırıklarda daha başarılı olduğunu söyleyebiliriz.

Anahtar sözcükler: Distal tibia; kırık; MIPO; yanlış kaynama.

Ulus Travma Acil Cerrahi Derg 20 I6;22(I):52-57 doi: 10.5505/tjtes.2015.82026 